\title{
Floating treatment wetlands for domestic wastewater treatment
}

\author{
J. L. Faulwetter, M. D. Burr, A. B. Cunningham, F. M. Stewart,
}

A. K. Camper and O. R. Stein

\begin{abstract}
Floating islands are a form of treatment wetland characterized by a mat of synthetic matrix at the water surface into which macrophytes can be planted and through which water passes. We evaluated two matrix materials for treating domestic wastewater, recycled plastic and recycled carpet fibers, for chemical oxygen demand (COD) and nitrogen removal. These materials were compared to pea gravel or open water (control). Experiments were conducted in laboratory scale columns fed with synthetic wastewater containing COD, organic and inorganic nitrogen, and mineral salts. Columns were unplanted, naturally inoculated, and operated in batch mode with continuous recirculation and aeration. COD was efficiently removed in all systems examined ( $>90 \%$ removal). Ammonia was efficiently removed by nitrification. Removal of total dissolved $\mathrm{N}$ was $\sim 50 \%$ by day 28 , by which time most remaining nitrogen was present as $\mathrm{NO}_{3}-\mathrm{N}$. Complete removal of $\mathrm{NO}_{3}-\mathrm{N}$ by denitrification was accomplished by dosing columns with molasses. Microbial communities of interest were visualized with denaturing gradient gel electrophoresis (DGGE) by targeting specific functional genes. Shifts in the denitrifying community were observed post-molasses addition, when nitrate levels decreased. The conditioning time for reliable nitrification was determined to be approximately three months. These results suggest that floating treatment wetlands are a viable alternative for domestic wastewater treatment.
\end{abstract}

Key words | bacteria, biofilm, COD, denitrification, floating treatment wetland, nitrification

\section{INTRODUCTION}

A type of artificial wetland in which emergent plants are grown either hydroponically or in a media floating on the surface of a pond-like basin has been used for habitat enhancement or contaminant amelioration since at least the mid-1970s (Seidel \& Happel I986; Hoeger I988). As with more conventional surface flow and subsurface flow treatment wetlands, Floating Treatment Wetlands (FTW) have been employed for removal and treatment of a diverse array of contaminants and polluted waters (Headley \& Tanner 2008b). However, due to their ability to float with relatively large fluctuations in water level, treatment of stormwater (Headley \& Tanner 2008a, b) and combined sewer overflow (Van de Moortel et al. 20Iob) appear to be the most typical applications. Natural floating islands, which can exist in locations where plant growth exceeds decay rates, maintain buoyancy via trapped gasses within a matrix of partially decayed and living plant material doi: $10.2166 /$ wst.2011.576

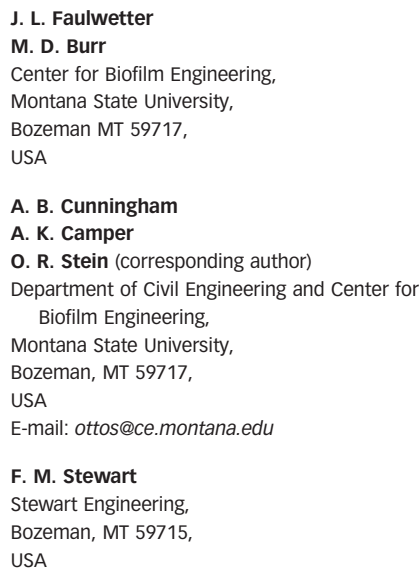

(Mitsch \& Gosselink 2000). Ayaz \& Saygin (1996) describe a completely hydroponic system, but most other FTW employ a superstructure frame constructed of buoyant material (PVC, bamboo, polystyrene, etc.) (Hoeger I988; Billore et al. 2008; Van de Moortel et al. 20I0a, 20Iob), are supported by cables attached to the bank (Kerr-Upal et al. 200o), or are constructed from an inherently buoyant planting media (Todd et al. 2003; Headley \& Tanner 2008a; Stewart et al. 2008). Depending on the thickness of the planting media and species of emergent plants employed, roots can be completely contained within the media or extend through and be exposed directly to the water column below.

Compared to other treatment wetland systems, design of FTW is based on very limited information and most applications seem to be unique for even the most basic parameters such as size, degree of buoyancy, planting media, plant selection, etc. Only a few studies (e.g. Headley \& 
Tanner 2008a; Nakai et al. 2008; Li et al. 20I0; Van de Moortel et al. 20IOa, 20Iob) have attempted to assess performance in replicated experiments and, due to the variety of designs and wastewater types and treatment objectives, performance generalizations are not possible at this time. To further advance understanding of processes important in FTW for domestic wastewater applications, we have been conducting experiments on chemical oxygen demand (COD) and nitrogen removal and associated microbial populations in FTW. An important criterion in FTW design is the type of planting media (matrix). An inherently buoyant matrix avoids the use of a supporting frame and we have focused attention on various buoyant matrix materials available through a local commercial provider. This paper summarizes research on the removal of COD and nitrogen species together with the dynamics of microbial communities occurring within two different matrix materials. The non-woven matrix is made of $100 \%$ recycled plastic fabricated into floating mats which can be configured, as shown in Figure 1, to include pumps for recirculation as well as aeration systems at various points within the matrix. By varying flow rate, duration and frequency of recirculation and aeration it is possible to control nutrient loading rates and redox conditions within the FTW matrix.

Previous research with these matrix materials conducted in outdoor ponds provided observations of the

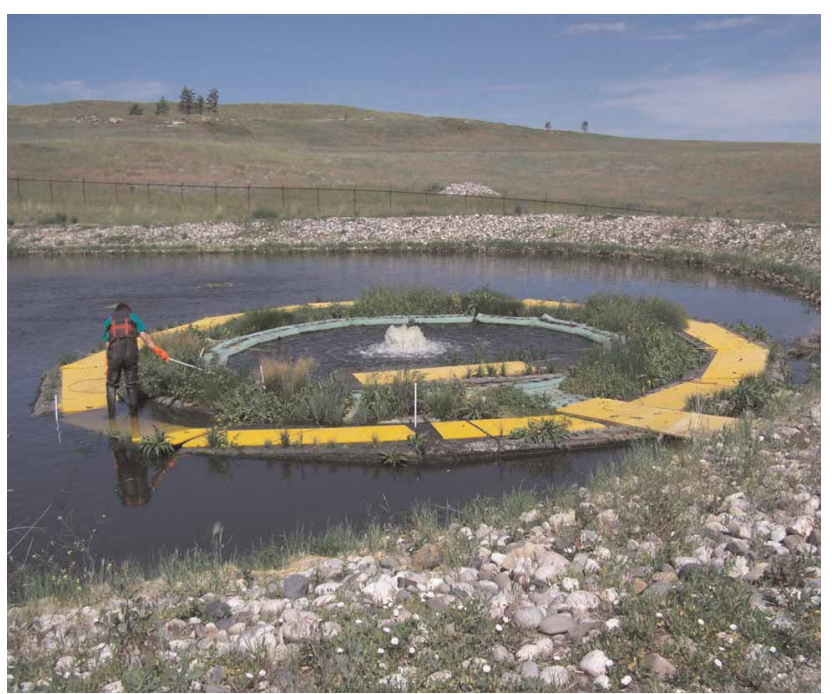

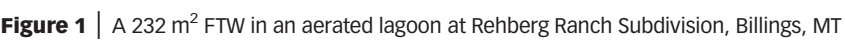
USA. The FTW is circular, with a radial fountain pump installed in the center. The body of the island is designed to float below the surface in order to maximize constituent uptake by biofilms growing on the plastic matrix. Parameters being tracked include suspended solids, BOD, nitrogen and phosphorus. The island was installed by Headwaters Floating Island, LLC during November 2009, and planted during the spring of 2010. Periodic water quality testing is being provided by the City of Billings, MT and Floating Island International, LLC. substantial disappearance of key wastewater constituents including COD, ammonia, nitrate and phosphate (Stewart et al. 2008). Since plants were not incorporated, constituent removal in these outdoor experiments was likely due to the activity of microorganisms growing as biofilms on surfaces within the island matrix. The objective of the current study is twofold: (1) determine the optimum operational conditions to encourage simultaneous nitrification (ammonia removal) and denitrification (nitrate removal) within a FTW environment by stimulating the appropriate microbial communities; and (2) determine the microbial community response to variations in aeration, matrix material and organic carbon loading. Successful completion of this research will not only provide the basis for improving FTW design and efficacy, but will provide insight into the processes responsible for effective water quality remediation occurring within FTW.

\section{METHODS}

Experiments were conducted in laboratory scale systems consisting of $20 \mathrm{~cm}$ diameter columns containing matrix material $20 \mathrm{~cm}$ thick submerged $10 \mathrm{~cm}$ below the water surface. Matrix material was either a very porous commercial mat made from $100 \%$ recycled plastic or loose shredded carpet fibers contained within a porous mesh, both supplied by Floating Island International (www.floatingislandinternational. com). Additionally, two otherwise identical columns, one filled with $20 \mathrm{~cm}$ pea gravel, the other left as open water, were included for comparison. Columns were each filled with 20 liters of simulated domestic wastewater containing $\sim 500 \mathrm{mg} / \mathrm{L}$ COD (mostly from sucrose), $\sim 15 \mathrm{mg} / \mathrm{L}$ $\mathrm{NH}_{4}-\mathrm{N}$ and $\sim 15 \mathrm{mg} / \mathrm{L} \mathrm{NO}_{3}-\mathrm{N}, \sim 30 \mathrm{mg}$ organic N/L from Primatone (Sigma), and other inorganic components (Taylor et al. 20II). All columns were unplanted, inoculated with soil and pond water, and operated in batch mode with continuous recirculation from the bottom of the column (at $20 \mathrm{~mL} / \mathrm{min}$ ) with continuous aeration (unless noted) from aquarium pumps into the surface water $10 \mathrm{~cm}$ above the matrix. We summarize data from five consecutive batch runs (B1-B5) that followed a conditioning period of four batches over a three month period. B1, B2, and B3 were run for 28 days. B4 and B5 were run for 42 days. During B4, columns were dosed with $10 \mathrm{~g}$ molasses (measured as $820 \mathrm{mg} \mathrm{COD} / \mathrm{g}$ ) on day 25 and again on day 29 in order to provide reducing equivalents for denitrification. There was no aeration during days 29-42. 


\section{Water quality analysis}

Water samples were collected from the recirculating return flow on days $0,3,8,14,21$, and 28 of batches B1-B3. Additional sampling during B4 and B5 was on days 35 and 42. Samples were filtered through a $0.2 \mu \mathrm{m}$ PES filter and stored in glass scintillation vials $\left(4^{\circ} \mathrm{C}\right)$. Samples were analyzed for $\mathrm{COD}, \mathrm{NH}_{4}-\mathrm{N}$, and total $\mathrm{N}$ using $\mathrm{HACH}$ (Loveland, $\mathrm{CO}$ ) methods. $\mathrm{NO}_{2}-\mathrm{N}$ and $\mathrm{NO}_{3}-\mathrm{N}$ were measured by ion chromatography (Dionex Corp., Sunnyvale, CA).

\section{Floating Island biofilm collection and DNA extraction}

Biofilm samples were collected on Day 0 of B3 (by which time columns were well conditioned) and again on Day 0 of B5 (14 days after the second molasses dose during B4) from three depths within each treatment: top (upper $5 \mathrm{~cm}$ of material), center (middle $5 \mathrm{~cm}$ of material), and bottom (lower $5 \mathrm{~cm}$ of material). To clearly distinguish between depths sampled, a $2.5 \mathrm{~cm}$ zone was left undisturbed between each of the locations. The open water column was sampled by vacuum filtering $250 \mathrm{~mL}$ of effluent through a $0.2 \mu \mathrm{m}$ polycarbonate membrane. Field samples from unplanted FTW, operated by Floating Island International, were also provided and analyzed for comparison with our laboratory samples. Materials collected from each treatment were placed directly into MO BIO PowerBead Tubes (MO BIO PowerSoil $^{\mathrm{TM}}$ DNA Isolation Kit). The PowerSoil ${ }^{\mathrm{TM}}$ DNA Isolation Kit was used to complete the DNA extraction as described in the manufacturer's protocol with the exception that PowerBead tubes were placed into the FastPrep ${ }^{\circledR}$ Instrument (Qbiogene, Inc.) at speed 5.5 for $45 \mathrm{~s}$. DNA yield was estimated on an agarose gel with ethidium bromide staining, serial dilutions were performed for PCR, and the DNA preparations were stored at $-20^{\circ} \mathrm{C}$.

\section{PCR targeting functional genes}

\section{Ammonia monooxygenase gene}

Oligonucleotide primers were synthesized by Integrated DNA Technologies (www.idtdna.com). PCR primers RottF (5'-GGGGTTTCTACTGGTGGT-3', Rotthauwe et al. 1997 amo $A-1 \mathrm{~F})$ and RottR (5'-CCCCTCKGSAAAGCCTTCTTC- ${ }^{\prime}$, Rotthauwe et al. 1997 - amoA-2R) target the ammonia monooxygenase gene (amoA, required for ammonia oxidation to nitrite). Primer RottR was synthesized with a $5^{\prime}$ 40-bp GC clamp (5'-CGCCCGCCGCGCCCCGCGCCCGG CCCGCCGCCCCCGCCCC-3', Ferris et al. 1996) and was paired with primer RottF for amplifying fragments to be analyzed by denaturing gradient gel electrophoresis (DGGE). Presumptive presence of the amoA gene was indicated on an agarose gel by a $531 \mathrm{bp}$ PCR product. PCR reactions $(20 \mu \mathrm{L})$ were performed using 2X GoTaq ${ }^{\circledR}$ Green Master Mix (www.promega.com). The PCR reaction mixture consisted of $10 \mu \mathrm{L} 2 \mathrm{X}$ GoTaq $^{\circledR}$ Green Master Mix, $0.5 \mu \mathrm{L}$ Ultrapure BSA ( $50 \mathrm{mg} / \mathrm{mL}$, Ambion), $2.5 \mu \mathrm{L}$ DEPC-treated water, $1 \mu \mathrm{L} 12.5 \mu \mathrm{M}$ forward and reverse primer, and $5 \mu \mathrm{L}$ 1:10 diluted (unquantified) template DNA. PCR amplifications were performed on an Eppendorf Mastercycler ${ }^{\circledR} \mathrm{ep}$ thermal cycler (Eppendorf North America, www.eppendorfna.com) using the following program. An initial denaturation for $60 \mathrm{~s}$ at $94^{\circ} \mathrm{C}$ was followed by a total of 35 cycles of amplification consisting of denaturation at $94^{\circ} \mathrm{C}$ for $60 \mathrm{~s}$, annealing at $54^{\circ} \mathrm{C}$ for $60 \mathrm{~s}$, and extension at $72^{\circ} \mathrm{C}$ for $3 \mathrm{~min}$. The program ended with an extension step at $72{ }^{\circ} \mathrm{C}$ for $10 \mathrm{~min}$ (Bahr et al. 2005). PCR products were confirmed by agarose gel electrophoresis and staining with ethidium bromide and were used for DGGE.

\section{Nitrite reductase gene}

Oligonucleotide primers were synthesized by Integrated DNA Technologies (www.idtdna.com). PCR primers NirS cd3aF (5' GTSAACGTSAAGGARACSGG 3', Michotey et al. 2000) and NirS R3cdR (5' GASTTCGGRTGSGTC TTGA 3', Throback et al. 2004) along with NirK F1aCuF (5' ATCATGGTSCTGCCGCG 3', Hallin \& Lindgren I999) and NirK R3CuR (5' GCCTCGATCAGRTTGTGGTT 3', Hallin \& Lindgren 1999) target the two forms of the nitrite reductase gene (nir, required for nitrite reduction to nitric oxide). Primers NirS R3cdR and NirK R3CuR were synthesized with a $5^{\prime}$ 40-bp GC clamp (described above) and were paired with their respective forward primers for amplifying fragments to be analyzed by DGGE. Presumptive presence of the nirS and nirK genes was indicated on an agarose gel by a $465 \mathrm{bp}$ or a $502 \mathrm{bp}$ PCR product, respectively. PCR amplifications were performed on an Eppendorf Mastercycler ${ }^{\circledR}$ ep thermal cycler (Eppendorf North America, www.eppendorfna.com) using the following program. An initial denaturation for $2 \mathrm{~min}$ at $94{ }^{\circ} \mathrm{C}$ was followed by a total of 35 cycles of amplification consisting of denaturation at $94^{\circ} \mathrm{C}$ for $30 \mathrm{~s}$, annealing at $57^{\circ} \mathrm{C}$ for $60 \mathrm{~s}$, and extension at $72^{\circ} \mathrm{C}$ for $60 \mathrm{~s}$. The program ended with an extension step at $72{ }^{\circ} \mathrm{C}$ for $10 \mathrm{~min}$ (Throback et al. 2004). PCR products were confirmed by agarose gel electrophoresis and staining with ethidium bromide and were used for DGGE. 


\section{Denaturing gradient gel electrophoresis}

DGGE was performed on PCR products from community DNA using a DCode ${ }^{\mathrm{TM}}$ system (www.biorad.com) and reagents from Sigma-Aldrich (www.sigmaaldrich.com). Gels had a gradient of denaturant concentrations from $40 \%$ at the top of the gel to $70 \%$ at the bottom, where $100 \%$ denaturant is defined as $7 \mathrm{M}$ urea and $40 \%$ formamide. Gels also contained an $8-12 \%$ polyacrylamide gradient from top to bottom (Girvan et al. 2003). Electrophoresis was at $60 \mathrm{~V}$ for $16 \mathrm{~h}$. Gels were stained with Sybr ${ }^{\circledR}$ Gold (www.invitrogen.com) and documented using a FluorChem ${ }^{\mathrm{TM}} 8800$ fluorescence imager (www. alphainnotech.com). Three marker lanes (generated from five pooled clones) were included in each DGGE gel so that lane profiles within and between gels could be compared. Bands in DGGE images were identified visually on a presenceabsence basis. Band intensities were not physically measured, but visually prominent bands were considered to represent numerically significant members of the community.

\section{DGGE data analysis}

DGGE gels were compared and analyzed for each gene investigated using the GelCompar II software (Version 6.1, Applied Maths Inc.). Subsequent statistical analyses were performed using R software libraries labdsv (Roberts 2009) and optpart (Roberts 20I0) (www.r-project.org). Similarity and dissimilarity matrices were calculated using Dice (GelCompar II) and Sorensen (R). Hierarchical clusters were generated from these matrices and displayed using the Unweighted Pair Group Method using Arithmetic averages (UPGMA). This method displays the average similarity between profiles for each sample compared. Hierarchical clusters displayed were generated from the similarity matrix calculated using the GelCompar II software; while more robust statistical analyses were performed using the dissimilarity matrix calculated using the $\mathrm{R}$ software. Reported large $\mathrm{D}^{2}$ values (similar to $\mathrm{R}^{2}$ ) indicate more confidence in the resultant clusters whereas small $p$-values (determined using the chi-squared test) indicated that the clusters represented the dataset well.

\section{RESULTS AND DISCUSSION}

\section{Water quality}

Because all water quality analyses were done on filtered samples $(0.2 \mu \mathrm{m}$ pore size), bacterial cells were excluded.
The laboratory columns containing plastic matrix, carpet fibers, pea gravel or open water were all effective at removing COD and nitrogen (Figure 2). There was relatively little difference among treatments (except as noted below). COD removal in all treatments was $\sim 90 \%$ within the first two weeks of each batch, i.e., from $\sim 500 \mathrm{mg}$ COD/L initially to $<50 \mathrm{mg} \mathrm{COD} / \mathrm{L}$ by day 14 . Initial total dissolved nitrogen was $\sim 60 \mathrm{mg} \mathrm{N} / \mathrm{L}$, consisting of $\sim 30 \mathrm{mg} \mathrm{N} / \mathrm{L}$ organic $\mathrm{N}$ (from Primatone), $\sim 15 \mathrm{mg} \quad \mathrm{NO}_{3}-\mathrm{N} / \mathrm{L}$, and $\sim 15 \mathrm{mg} \mathrm{NH}_{4}-\mathrm{N} / \mathrm{L}$. Total dissolved $\mathrm{N}$ generally decreased by $\sim 50 \%$ within the first two weeks, but leveled off after that. In the first week, removal of $\mathrm{NO}_{3}-\mathrm{N}$ was usually $\sim 90 \%$, probably from denitrification. $\mathrm{NH}_{4}-\mathrm{N}$ usually increased in the first week, probably from mineralization of organic N. An exception was the gravel column where $\mathrm{NH}_{4}-\mathrm{N}$ decreased immediately. This
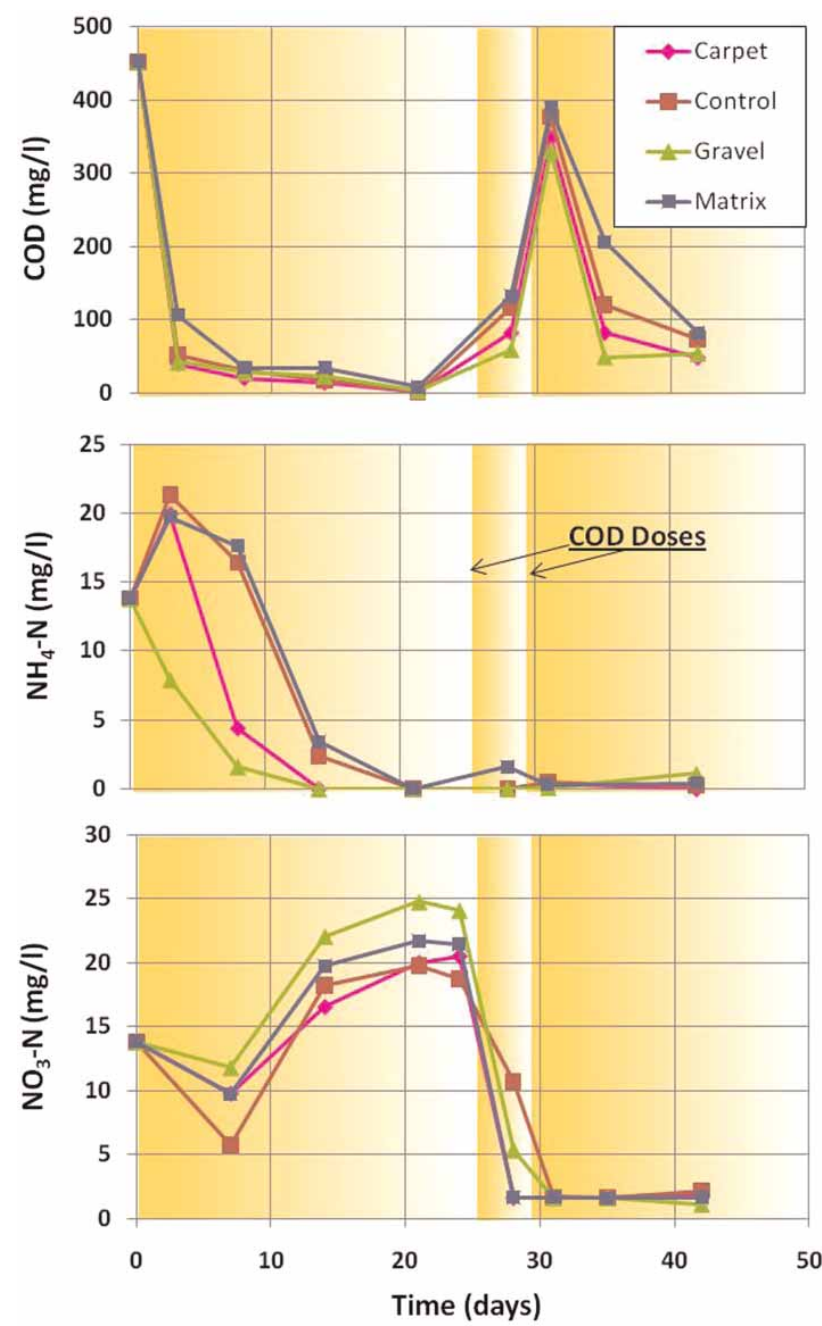

Figure 2 | Water quality from batch B4 showing addition of COD doses (as molasses) to remove accumulated nitrate by stimulating the denitrifying biofilm community. Aeration was turned off after dosing for the remainder of the batch. 
behavior may have been the result of adsorption onto the gravel matrix and has been observed in previous studies using the same gravel (Riley et al. 2005). By days 21-28, $\mathrm{NO}_{3}-\mathrm{N}$ usually began to accumulate again and often accounted for most of the total $\mathrm{N}$. There was usually a corresponding loss of $\mathrm{NH}_{4}-\mathrm{N}$ during this time period, indicating that nitrification was occurring. Differences in nitrification between new and conditioned plastic matrix suggested that about three months were required to establish an effective nitrifying biofilm community. By day 28 in batches B1-B3, the columns had reached a steady state in which COD was virtually absent, and almost all of the total dissolved $\mathrm{N}$ was as $\mathrm{NO}_{3}-\mathrm{N}(\sim 20$ to $30 \mathrm{mg} \mathrm{N} / \mathrm{L})$. To test the hypothesis that denitrification in these batches had been carbon-limited, we introduced doses of molasses (10 g molasses/column) on days 25 and 29 of B4. Dosing produced a spike in COD (to $\sim 370 \mathrm{mg}$ COD/L), but by the end of the batch two weeks later, $>90 \%$ of this COD had also been removed. The molasses was effective at increasing denitrification. By the end of the batch on day 42, total dissolved $\mathrm{N}$ was $<5 \mathrm{mg} \mathrm{N} / \mathrm{L}, \mathrm{NO}_{3}-\mathrm{N}$ was $<4 \mathrm{mg} \mathrm{N} / \mathrm{L}$, and $\mathrm{NH}_{4}-\mathrm{N}$ was $<2 \mathrm{mg} \mathrm{N} / \mathrm{L}$. COD was $<100 \mathrm{mg} / \mathrm{L}$, but this residual COD from the molasses would probably have been removed had the batch been allowed to run beyond day 42. Batch B5 produced results that were similar to B4. $\mathrm{NO}_{2}-\mathrm{N}$ was not a component of the synthetic wastewater and was usually $\leq 1 \mathrm{mg} \mathrm{N} / \mathrm{L}$ for all treatments and time points.

Synthetic wastewater (completely soluble) was used in these column experiments. Additional pretreatment may be necessary when implementing FTW for wastewaters containing grit and suspended solids, etc.

\section{Microbial community responses}

The responses of the nitrifying and denitrifying microbial communities were monitored using DGGE. Interpretation of DGGE profiles was done cautiously as they are invariably a mix of artifact and real diversity. Individual bands are generally assumed to represent individual genotypes, but only DNA sequencing can confirm this. The total number of bands in a profile is a rough estimate of diversity and the intensity of a band is a rough estimate of the prominence of the corresponding genotype in the microbial community (Muyzer et al. I993). It should be noted that bands suspected to be artifact were not included in the analysis and as a result, diversity may have been underestimated. Analysis of DGGE gels was performed using Gel Compar II software (v. 6.1, Applied Maths Inc.) to visualize and compare gels.
Statistical analyses were performed based on band presence/absence within each profile using the $\mathrm{R}$ software libraries labdsv (Roberts 2009) and optpart (Roberts 20IO) (www.r-project.org).

\section{Nitrifying community}

The nitrifying communities within each column were observed to have limited diversity (maximum of 12 bands observed, gravel treatment, Figure 3). The open water column had developed a distinct nitrifying community unlike any of the other treatment conditions $\left(D^{2}=0.9944\right)$. Dosing with molasses and ending aeration did not significantly affect the structure of the nitrifying communities. The community structure of the laboratory versus field samples were distinctly different $\left(D^{2}=0.9955\right)$. Field samples generally contained 5-7 bands, while laboratory samples contained 5-12 bands. It appeared that sample depth within the column was the most significant factor in community structure $(p<0.001$, Figure 3$)$ followed by FTW material used ( $p=0.01)$, with matrix and carpet communities being more similar to one another than to the gravel community.

\section{Denitrifying community}

In order to investigate the entire denitrifying community present, both the nirS and nirK genes were characterized. Overall, the denitrifying community profiles were

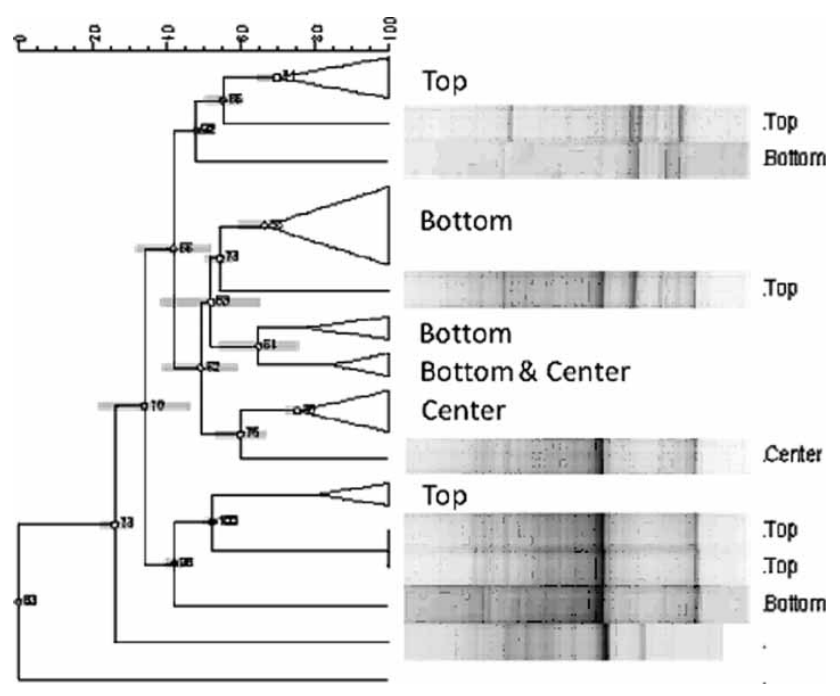

Figure 3 Community profiles of amoA, the marker gene for nitrifiers. Triangles indicate that the samples within were similar enough to combine into a single cluster. Top - upper $5 \mathrm{~cm}$ of FTW material; Center - middle $5 \mathrm{~cm}$ of material; Bottom lower $5 \mathrm{~cm}$ of material; unlabelled rows indicate open water column. 


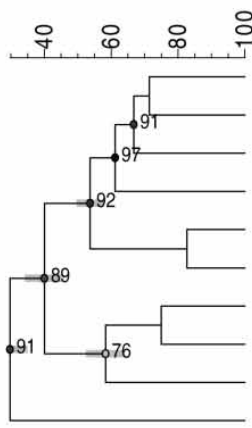

Pre molasses addition
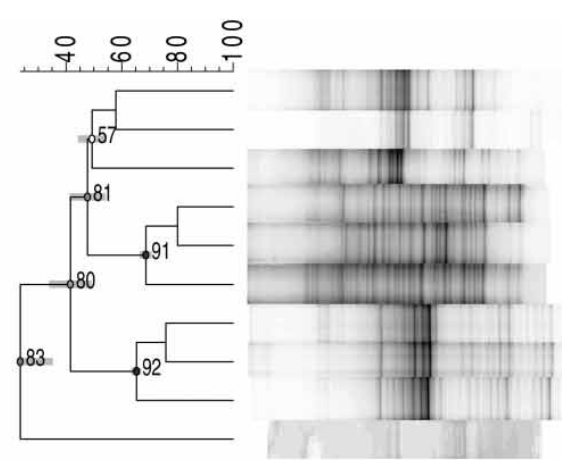

- Matrix Top August

- Matrix Center August

- Matrix Bottom August

$\star$ Carpet Center August

$\star$ Carpet Bottom August

$\star$ Carpet Top August

- Gravel Center August

- Gravel Bottom August

- Gravel Top August

$\odot$ Control August

Figure 4 | Community profiles for nirs pre- and post-addition of molasses. FTW material tended to determine community profiles before addition of molasses (left), and post-addition (right), each material had developed a distinct nirs community, as observed with the four grouped clusters.

considerably more diverse compared to the nitrifying community profiles. As observed with the nitrifying community profile, the profiles for the open water column had developed unique communities compared to the other treatments $\left(D^{2}=1\right.$, for both genes). For the nirK gene, the communities were highly diverse, but apparent similarities were specific to the FTW matrix material within the column $\left(D^{2}=0.9996, p=0.005\right)$. For the nirS gene, the FTW matrix material was most important in determining the community that developed $(p<0.001)$ with all of the gravel samples grouping onto a single branch. Adding molasses and ending aeration also appeared to affect the nirS denitrifying community, though not as greatly as FTW material had ( $p=0.05$, Figure 4). Finally, the field samples had developed significantly different denitrifying communities for the nirS $(p=0.001)$ but not the nirK gene.

\section{CONCLUSIONS}

As expected, all treatments (regardless of material) were able to efficiently remove COD. Additionally, communities cultivated in the field versus laboratory conditions developed their own unique consortia for each of the genes investigated.

Distance from the water surface (depth) appeared to be the most important determinant of the structure of the nitrifying community, followed by FTW matrix material. Elimination of aeration and addition of molasses did not appear to alter the established nitrifying community, indicating that it may be important to first establish an efficient nitrifying community, then optimize for subsequent nitrate removal. Aeration rates were not optimized in this study. Future research will focus on designing appropriate aeration schedules for full scale field operation.
FTW matrix material had the largest effect on the denitrifying community. As observed with the nitrifiers, the elimination of aeration and addition of molasses did not significantly affect the community structure, but did stimulate denitrifying activity and thus nitrate removal.

\section{ACKNOWLEDGEMENTS}

This study was supported by the Montana Board of Research and Commercialization Technology (MBRCT), Grant Agreement \#09-26. FTW matrix materials were provided by Floating Island International, LLC, Shepherd, MT. We would like to thank Bennett Hisey and Rachel Van Kempen-Fryling for their assistance in sample collection and processing throughout this project.

\section{REFERENCES}

Ayaz, S. C. \& Saygin, O. I996 Hydroponic tertiary treatment. Water Research 30, 1295-1298.

Bahr, M., Crump, B. C., Klepac-Ceraj, V., Teske, A., Sogin, M. L. \& Hobbie, J. E. 2005 Molecular characterization of sulfatereducing bacteria in a New England salt marsh. Environmental Microbiology 7, 1175-1185.

Billore, S. K., Prashant, J. K., Sharma, N., Singh, H., Ram, P. \& Dass, R. J. 2008 Restoration and conservation of stagnant water bodies by gravel-bed treatment wetlands and artificial floating reed beds in tropical India. In Preprints of 11th International Conference on Wetland Systems for Water Pollution Control, Indore, India, pp. 408-414.

Ferris, M. J., Muyzer, G. \& Ward, D. M. I996 Denaturing gradient gel electrophoresis profiles of 16S rRNA-defined populations inhabiting a hot spring microbial mat community. Applied and Environmental Microbiology 62, 340-346.

Girvan, M. S., Bullimore, J., Pretty, J. N., Osborn, A. M. \& Ball, A. S. 2003 Soil type is the primary determinant of the 
composition of the total and active bacterial communities in arable soils. Applied and Environmental Microbiology 69, 1800-1809.

Hallin, S. \& Lindgren, P. E. I999 PCR detection of genes encoding nitrile reductase in denitrifying bacteria. Applied and Environmental Microbiology 65, 1652-1657.

Headley, T. R. \& Tanner, C. C. 2008a Floating treatment wetlands for the removal of fine particulates, copper and zinc from stormwater. In Preprints of 11th International Conference on Wetland Systems for Water Pollution Control, Indore, India, pp. 655-659.

Headley, T. R. \& Tanner, C. C. 2008b Floating treatment wetlands: an innovative option for stormwater quality applications. In Preprints of 11th International Conference on Wetland Systems for Water Pollution Control, Indore, India, pp. 1101-1106.

Hoeger, S. 1988 Schwimmkampen - Germany's artificial floating islands. Journal of Soil and Water Conservation 43, 304-306.

Kerr-Upal, M., Seasons, M. \& Mulamoottil, G. 2000 Retrofitting a stormwater management facility with a wetland component. Journal of Environmental Science and Health Part A-Toxic/ Hazardous Substances \& Environmental Engineering 35, 1289-1307.

Li, X.-N., Song, H.-L., Li, W., Lu, X.-W. \& Nishimura, O. 2010 An integrated ecological floating-bed employing plant, freshwater clam and biofilm carrier for purification of eutrophic water. Ecological Engineering 36, 382-390.

Michotey, V., Mejean, V. \& Bonin, P. 2000 Comparison of methods for quantification of cytochrome cd(1)-denitrifying bacteria in environmental marine samples. Applied and Environmental Microbiology 66, 1564-1571.

Mitsch, W. \& Gosselink, J. 2000 Wetlands. John Wiley and Sons, New York, USA, 539 pp.

Muyzer, G., Dewaal, E. C. \& Uitterlinden, A. G. I993 Profiling of complex microbial populations by denaturing gradient gel electrophoresis analysis of polymerase chain reactionamplified genes coding for $16 \mathrm{~S}$ ribosomal-RNA. Applied and Environmental Microbiology 59, 695-700.

Nakai, S., Okuda, T., Nishijima, W. \& Okada, M. 2008 Anticyanobacterial allelopathic effects of plants used for artificial floating islands. In Preprints of 11th International Conference on Wetland Systems for Water Pollution Control, Indore, India, pp. 284-289.

Riley, K. A., Stein, O. R. \& Hook, P. B. 2005 Ammonium removal in constructed wetland microcosms as influenced by presence and species of plants and organic carbon load. Journal of Environmental Science and Health Part A $\mathbf{4 0}$ (6-7), 1109-1121.

Roberts, D. W. 2009 labdsv: Ordination and multivariate analysis for ecology. R package version 1.3-3. Available from: http://ecology.msu.montana.edu/labdsv/R (accessed 28 June 2010).

Roberts, D. W. 2010 optpart: Optimal partitioning of similarity relations. R package version 2.0-1. Available from: http:// CRAN.R-project.org $/$ package $==$ optpart $($ accessed 28 June 2010)

Rotthauwe, J. H., Witzel, K. P. \& Liesack, W. 1997 The ammonia monooxygenase structural gene amo $A$ as a functional marker: Molecular fine-scale analysis of natural ammoniaoxidizing populations. Applied and Environmental Microbiology 63, 4704-4712.

Seidel, K. \& Happel, H. 1986 Teiche und pflanzen in der abwasserreinigung (Ponds and plants in wastewater treatment). Wasserkalender 20, 123-147 (in German).

Stewart, F. M., Mulholland, T., Cunningham, A. B., Kania, B. G. \& Osterlund, M. T. 2008 Floating islands as an alternative to constructed wetlands. Land Contamination and Reclamation 16, 25-34.

Taylor, C. R., Stein, O. R., Hook, P. B. \& Zabinski, C. A. 20 II Seasonal effects of 19 plant species on COD removal in subsurface treatment wetland microcosms. Ecological Engineering 37, 703-710.

Throback, I. N., Enwall, K., Jarvis, A. \& Hallin, S. 2004 Reassessing PCR primers targeting nirS, nirK and nos $Z$ genes for community surveys of denitrifying bacteria with DGGE. FEMS Microbiology Ecology 49, 401-417.

Todd, J., Brown, E. J. G. \& Wells, E. 2003 Ecological design applied. Ecological Engineering 20, 421-440.

Van de Moortel, A. M. K., De Pauw, N. \& Tack, F. M. G. 2oroa Influence of water depth, coverage and aeration on the treatment efficiency of experimental constructed floating wetlands. In Preprints of Society of Wetland Scientists European Chapter, Tramore, Ireland, pp. 78-79.

Van de Moortel, A. M. K., Meers, E., De Pauw, N. \& Tack, F. M. G. 2orob Effects of vegetation, season, and temperature on the removal of pollutants in experimental floating treatment wetlands. Water Air and Soil Pollution 212, 281-297. 